\title{
Adipose tissue protects against sepsis- induced muscle weakness in mice: from lipolysis to ketones
}

\author{
Chloë Goossens ${ }^{1}$, Ruben Weckx', Sarah Derde ${ }^{1}$, Thomas Dufour ${ }^{1}$, Sarah Vander Perre ${ }^{1}$, Lies Pauwels ${ }^{1}$,
} Steven E. Thiessen ${ }^{1}$, Paul P. Van Veldhoven ${ }^{2}$, Greet Van den Berghe ${ }^{1+}$ and Lies Langouche ${ }^{1 *^{+}}$(D)

\begin{abstract}
Background: ICU-acquired weakness is a debilitating consequence of prolonged critical illness that is associated with poor outcome. Recently, premorbid obesity has been shown to protect against such illness-induced muscle wasting and weakness. Here, we hypothesized that this protection was due to increased lipid and ketone availability.
\end{abstract}

Methods: In a centrally catheterized, fluid-resuscitated, antibiotic-treated mouse model of prolonged sepsis, we compared markers of lipolysis and fatty acid oxidation in lean and obese septic mice $(n=117)$. Next, we compared markers of muscle wasting and weakness in septic obese wild-type and adipose tissue-specific ATGL knockout (AAKO) mice $(n=73)$, in lean septic mice receiving either intravenous infusion of lipids or standard parenteral nutrition (PN) $(n=70)$, and in lean septic mice receiving standard PN supplemented with either the ketone body 3hydroxybutyrate or isocaloric glucose $(n=49)$.

Results: Obese septic mice had more pronounced lipolysis ( $p \leq 0.05)$, peripheral fatty acid oxidation $(p \leq 0.05)$, and ketogenesis $(p \leq 0.05)$ than lean mice. Blocking lipolysis in obese septic mice caused severely reduced muscle mass ( $32 \%$ loss vs. $15 \%$ in wild-type, $p<0.001$ ) and specific maximal muscle force (59\% loss vs. $0 \%$ in wild-type; $p<0.001$ ). In contrast, intravenous infusion of lipids in lean septic mice maintained specific maximal muscle force up to healthy control levels $(p=0.6)$, whereas this was reduced with $28 \%$ in septic mice receiving standard PN $(p=0.006)$. Muscle mass was evenly reduced with $29 \%$ in both lean septic groups $(p<0.001)$. Lipid administration enhanced fatty acid oxidation $(p \leq 0.05)$ and ketogenesis $(p<0.001)$, but caused unfavorable liver steatosis $(p=0.01)$ and a deranged lipid profile $(p \leq 0.01)$. Supplementation of standard PN with 3-hydroxybutyrate also attenuated specific maximal muscle force up to healthy control levels $(p=0.1)$, but loss of muscle mass could not be prevented $(25 \%$ loss in both septic groups; $p<0.001$ ). Importantly, this intervention improved muscle regeneration markers ( $p \leq$ 0.05) without the unfavorable side effects seen with lipid infusion.

Conclusions: Obesity-induced muscle protection during sepsis is partly mediated by elevated mobilization and metabolism of endogenous fatty acids. Furthermore, increased availability of ketone bodies, either through ketogenesis or through parenteral infusion, appears to protect against sepsis-induced muscle weakness also in the lean.

Keywords: Adipose tissue, Skeletal muscle, Sepsis, Metabolism, Muscle weakness

\footnotetext{
* Correspondence: lies.langouche@kuleuven.be

${ }^{\dagger}$ Greet Van den Berghe and Lies Langouche contributed equally to this work.

${ }^{1}$ Clinical Division and Laboratory of Intensive Care Medicine, Department of

Cellular and Molecular Medicine, KU Leuven, 3000 Leuven, Belgium

Full list of author information is available at the end of the article
}

(c) The Author(s). 2019 Open Access This article is distributed under the terms of the Creative Commons Attribution 4.0 International License (http://creativecommons.org/licenses/by/4.0/), which permits unrestricted use, distribution, and reproduction in any medium, provided you give appropriate credit to the original author(s) and the source, provide a link to the Creative Commons license, and indicate if changes were made. The Creative Commons Public Domain Dedication waiver (http://creativecommons.org/publicdomain/zero/1.0/) applies to the data made available in this article, unless otherwise stated. 


\section{Background}

Critically ill patients frequently develop weakness of limb and respiratory muscles. Such intensive care unit (ICU)-acquired weakness has a high prevalence and is associated with greater post-ICU impairment, prolonged hospitalization, delayed rehabilitation, and late death [1, 2]. Particularly patients suffering from sepsis are at risk of developing ICU-acquired weakness [3].

Profound loss of muscle mass and quality characterizes ICU-acquired weakness [4]. This loss of muscle mass is caused by activated myofibrillary breakdown without compensatory protein synthesis [5-8]. In addition, the loss of myofiber quality is related to insufficiently activated autophagy and ongoing inflammation [9-11]. Muscle regeneration is also severely impaired in prolonged critically ill patients, which hampers rehabilitation [12]. Several interventions, such as aggressive sepsis treatment, early mobilization, prevention of hyperglycemia, and withholding early parenteral nutrition (PN), have been shown to partially protect against ICUacquired weakness $[4,9,13,14]$. Nevertheless, to reduce the prevalence of this debilitating condition, additional clinical interventions are still required.

Recently, premorbid overweight/obesity has been shown to protect against muscle wasting and weakness in both critically ill patients and in septic mice [15]. In these septic mice, the overweight/obese preserved their muscle mass while losing fat mass. In contrast, lean septic mice prioritized the maintenance of fat mass over muscle mass [15]. Markers of fatty acid metabolism and ketogenesis also appeared more increased in overweight/ obese than in lean septic mice [15]. This suggested an intrinsically different metabolic response to sepsis with overweight/obesity. Importantly, diet-induced obesity does typically enhance basal lipolysis, hepatic lipid metabolism, fatty acid oxidation, and ketogenesis [16-23].

Such an altered metabolic response in obese individuals, with increased release and metabolism of fatty acids to ketones, might mediate the observed protection against sepsis-induced muscle wasting and weakness. Indeed, in patients suffering from pancreatic cancer cachexia, a high-fat, ketogenic diet protected against muscle wasting. Additionally, in elite athletes, muscle function improved after exogenous ketone body administration $[24,25]$. Ketone bodies exert several functions that could benefit the muscle during critical illness. As energy substrates, they can alter muscle substrate metabolism from the use of glycogen to 3-hydroxybutyrate (3-HB) [2527]. Furthermore, as signaling molecules, ketone bodies have anti-inflammatory and autophagy-stimulating actions and can induce mTOR-mediated protein synthesis and muscle regeneration [28-32].

As a general hypothesis, we state that the protection against ICU-acquired weakness in overweight/obese critically ill patients can be explained by their enhanced ability to release and metabolize fatty acids from their excess adipose tissue. This hypothesis was tested with four consecutive studies in a mouse model of prolonged abdominal sepsis [33]. Of note, this centrally catheterized, fluidresuscitated, and antibiotic-treated mouse model results in muscle wasting and weakness that is comparable to ICUacquired weakness in patients [15]. We aimed to assess (1) whether overweight/obesity causes enhanced mobilization and metabolism of endogenous fatty acids during sepsis and (2) whether such altered metabolic response protects the skeletal muscle. Furthermore, we aimed to evaluate (3) whether the obesity-induced muscle protection can be mimicked in lean septic mice by increased lipid availability. Lastly, we aimed to investigate (4) whether the observed muscle protection is mediated by ketone bodies that either function as alternative energy substrates or as signaling molecules.

\section{Methods \\ Animal study design}

Male, 24-week-old mice were anesthetized and a catheter was placed in the central jugular vein, followed by cecal ligation and puncture to induce sepsis [33, 34]. Unless indicated, 57BL/6JRj mice (Janvier SAS, Chassal, France) were used. After surgery, mice were fasted and received intravenous fluid resuscitation for $20 \mathrm{~h}$. Fasting was done to mimic the clinical setting in which PN is initially withheld. From day 1 onward, mice received standard mixed PN (5.8 kcal/day; Olimel N7E, Baxter, Lessines, Belgium) unless indicated. Throughout the study, mice were given antibiotics and pain medication. Pain/discomfort was assessed twice daily based on the Mouse Grimace Score [35], and cumulative illness scores were calculated to assess the severity of illness. Individually caged healthy mice receiving standard chow at the same daily caloric intake as septic mice (pair-fed) were used as controls.

\section{Study 1 - Fatty acid mobilization and metabolism in lean and overweight/obese septic mice $(n=117)$}

After 12 weeks on standard chow (10\% fat, E15745-04, ssniff, Soest, Germany) or a high-fat diet (45\% fat, E1574434 , ssniff), lean and overweight/obese mice were randomized to "healthy control" or "sepsis". They were sacrificed after either 1 or 5 days [day 1: lean healthy control $n=15$, obese healthy control $n=10$, lean sepsis $n=15$, obese sepsis $n=15$; day 5 : lean healthy control $n=17$, obese healthy control $n=15$, lean sepsis $n=15$, obese sepsis $n=15]$.

\section{Study 2 - Effect of blocking fatty acid mobilization in overweight/obese septic mice on muscle wasting and weakness $(n=73)$}

Adipose triglyceride lipase (ATGL)-flox mice were bred to Adipoq-Cre-mice to generate adipose tissue-specific 
ATGL knockout (AAKO; ATGL ${ }^{\text {flox/flox }} \mathrm{Cre} /+$ ) and wildtype (ATGL ${ }^{\text {flox/flox }}+/+$ ) mice (Additional file 5). After 12 weeks on a high-fat diet, overweight/obese AAKO and wild-type mice were randomized to "healthy control" or "sepsis" and sacrificed after 5 days [wild-type healthy control $n=19$, AAKO healthy control $n=18$, wild-type sepsis $n=19$, AAKO sepsis $n=17$ ].

\section{Study 3 - Effect of increased lipid availability on muscle wasting and weakness in lean septic mice $(n=70)$}

From day 1 of sepsis onward, lean septic mice randomly received isocaloric amounts of either standard mixed PN (Olimel N7E: $35 \%$ lipids, 49\% glucose and 16\% amino acids), or a lipid-rich PN consisting of mainly long- and medium-chain triglycerides $(5.8 \mathrm{kcal} /$ day obtained from: 90\% lipids (Smoflipid ${ }^{\circ}$ Lipid Injectable Emulsion, Fresenius Kabi, Schelle, Belgium, containing 30\% soybean oil, $30 \%$ medium-chain triglycerides, $15 \%$ fish oil and $25 \%$ olive oil) and $10 \%$ glucose). Mice were sacrificed after 5 days [healthy control $n=24$, sepsis receiving PN $n=23$, sepsis receiving lipid-rich $\mathrm{PN} n=23$ ].

\section{Study 4 - Effect of increased ketone body availability on muscle wasting and weakness in lean septic mice $(n=49)$}

From day 1 of sepsis onward, lean septic mice received standard mixed PN supplemented with twice-daily subcutaneous bolus injections of isocaloric and isovolumetric amounts of either D-glucose $(6.25 \mathrm{mg} / \mathrm{g} /$ day; $\mathrm{PN}$ +gluc) or D,L-3-HB sodium salt (5 mg/g/day; PN+3-HB) . Mice were sacrificed after 5 days [healthy control $n=15$, sepsis $\mathrm{PN}+$ gluc $n=17$, sepsis $\mathrm{PN}+3-\mathrm{HB} n=17]$.

All animals were treated according to the Principles of Laboratory Animal Care (U.S. national Society for Medical Research) and the Guide for Care and Use of Laboratory Animals (National Institutes of Health). The Institutional Ethical Committee for Animal Experimentation of the KU Leuven had approved the protocols for these animal studies (project numbers P50/2015 and P009/2016). Mice in study 1 were sacrificed after 1 or 5 days, to assess both the acute and prolonged lipolytic response to sepsis (plasma and ex vivo glycerol) [36, 37]. Mice in study 2-4 were sacrificed after 5 days, the timeframe required to develop sepsis-induced muscle weakness [15]. Assessment of muscle weakness by ex vivo muscle force measurements was the primary endpoint of these studies. Data on survival are provided in Table 1. Additional information is provided in Additional file 7.

\section{Ex vivo muscle force}

Directly after euthanasia, the extensor digitorum longus (EDL) muscle was carefully dissected and suspended in a temperature controlled $\left(30^{\circ} \mathrm{C}\right)$ organ bath filled with HEPES-fortified Krebs-Ringer solution to measure muscle force (300C-LR Dual-Mode muscle lever, Aurora Scientific, Ontario, Canada). The small size of the EDL guaranteed proper diffusion of oxygen during the procedure. Maximal isometric tetanic force of the EDL muscle was measured by averaging three consecutive tetanic stimuli $(180 \mathrm{~Hz}$ stimulation frequency, $200 \mathrm{~ms}$ duration, $0.2 \mathrm{~ms}$ pulse width, $2 \mathrm{~min}$ rest intervals). Specific maximal isometric tetanic force was calculated by dividing the maximal isometric tetanic force with the muscle cross-sectional area. Additional information is provided in Additional file 7.

\section{Tissue analyses}

For practical reasons, tibialis anterior (TA) muscle was used for histology and muscle mass assessment, whereas the larger gastrocnemius muscle was homogenized and used for gene, protein, and metabolite analyses.

\section{Tissue composition}

To eliminate potential bias from illness- or resuscitation-related changes in fluid content, dry weight of isolated tissues was obtained by a freeze-drying process. Triglyceride and glycogen content was measured with commercially available kits (triglyceride

Table 1 Survival until day 5 of septic mice in the different mouse cohorts

\begin{tabular}{|c|c|c|c|}
\hline & Randomization & 5-day survival (number, \%) & $p$ value \\
\hline \multirow[t]{2}{*}{ Study 1: Fatty acid mobilization and metabolism in lean and obese septic mice } & Lean & 15/18 (83) & \multirow[t]{2}{*}{1.0} \\
\hline & Obese & 15/18 (83) & \\
\hline \multirow[t]{2}{*}{ Study 2: Effect of blocking fatty acid mobilization in obese septic mice on the muscle } & Wild-type & 19/22 (86) & \multirow[t]{2}{*}{0.1} \\
\hline & AAKO & $17 / 25(68)$ & \\
\hline \multirow[t]{2}{*}{ Study 3: Effect of increased lipid availability on the muscle in lean septic mice } & PN & $23 / 25(92)$ & \multirow[t]{2}{*}{0.8} \\
\hline & Lipid PN & $23 / 26(88)$ & \\
\hline \multirow[t]{2}{*}{ Study 4: Effect of increased ketone body availability on the muscle in lean septic mice } & $\mathrm{PN}+$ gluc & $17 / 20(85)$ & \multirow[t]{2}{*}{0.8} \\
\hline & $\mathrm{PN}+3-\mathrm{HB}$ & $17 / 21(81)$ & \\
\hline
\end{tabular}

In all healthy control groups and day 1 septic mice, survival was $100 \%$. [AAKO adipose tissue-specific adipose triglyceride lipase knockout, $P N$ parenteral nutrition, Lipid $P N$ parenteral nutrition consisting mainly of long- and medium-chain triglycerides, $P N+$ gluc mice receiving $P N$ supplemented with glucose, $P N+3-H B$ mice receiving PN supplemented with ketone body 3-hydroxybutyrate] 
quantification kit Ab65336, glycogen assay kit Ab65620, Abcam, Cambridge, UK).

\section{Lipolysis}

Glycerol release was assessed in epididymal adipose tissue explants with a commercially available kit (Glycerol Assay Kit MAK117, Sigma-Aldrich, Saint Louis, MO, USA).

\section{Gene expression}

Messenger RNA was isolated, and cDNA was quantified in real time as previously documented [38]. Commercial TaqMan $^{\bullet}$ assays (Applied Biosystems, Carlsbad, CA, USA) were used for all gene expression analyses (Additional file 6: Table S1). Data were normalized to Rn18s or Hprt and expressed as fold change of the mean of controls.

\section{Protein expression analyses}

Protein isolation was executed as previously described [39]. Immunoblotting was performed with primary antibodies (Additional files 1, 2, 3, 4, 5, and 6) and secondary horseradish peroxidase-conjugated antibodies. Blots were visualized with the G:BOX Chemi XRQ (SynGene, Bangalore, India) and analyzed with SynGene software. Data were normalized to $\beta$-actin levels and expressed as fold change of the mean of controls.

\section{Histology}

Cross-sectional paraffin sections of TA muscle were stained with a monoclonal antibody against PAX7 (1/ 100, Mab1675, R\&D Systems, Minneapolis, MN, USA, RRID:AB_2159833) and a HRP-linked secondary antibody (Additional files 1, 2, 3, 4, 5, and 6). Histological scoring of liver steatosis was performed on hematoxylin and eosin-stained liver sections.

\section{Palmitate oxidation}

Oxidation of $\left[1-{ }^{14} \mathrm{C}\right]$-labeled fatty acids was measured in tissue homogenates using a HEPES-fortified modified Krebs-Henseleit buffer [40]. Oxidation rates are expressed as nmol produced $\left[{ }^{14} \mathrm{C}\right] \mathrm{CO}_{2}$ and $\left[{ }^{14} \mathrm{C}\right]$-labeled acid-soluble metabolites per gram wet weight per minute. Additional information is provided in Additional file 7 .

\section{Plasma analyses}

Plasma glucose concentrations were measured in whole blood with a glucose meter after cardiac puncture (Accu-check, Roche, Basel, Switzerland). Plasma glycerol, TNF- $\alpha, \mathrm{LDL}, \mathrm{HDL}$, triglycerides, free fatty acids, insulin, and 3-HB were measured using commercially available kits: Glycerol Assay Kit (MAK117, SigmaAldrich), Mouse TNF-alpha Quantikine HS ELISA Kit
(MHSTA50; R\&D Systems), LDL-Cholesterol assay (DZ128A-K; Diazyme Laboratories, Poway, CA, USA), HDL-Cholesterol assay (DZ129A-K; Diazyme), triglyceride quantification kit (Ab65336; Abcam), Free Fatty Acid Fluorometric Assay Kit (7010310; Cayman Chemical Company, Ann Arbor, MI, USA), Insulin Mouse Ultra Sensitive ELISA (90080, Crystal Chem, Downers Grove, IL, USA), and EnzyChrom ${ }^{\text {Tx }}$ Ketone Body Assay Kit (EKBD-100; Bioassay Systems, Hayward, CA, USA).

\section{Statistics}

Normally distributed data were compared with one-way analysis of variance (ANOVA) with post hoc Fisher's LSD test (Student's $t$ test) for multiple comparisons, where necessary, after log- or (double) square roottransformation to obtain a near-normal distribution (JMP ${ }^{\circ}$ Pro 12, SAS Institute Inc., Cary, NC, USA). Notnormally distributed data were analyzed with nonparametric Wilcoxon tests. Two-sided $p$ values $\leq 0.05$ $(\alpha$-level of $5 \%)$ were considered statistically significant in all analyses. Data are presented as bars with whiskers, showing means and standard error of the mean (SEM). Post hoc $p$ values are plotted on the figures as $\mathbb{P} \leq 0.05$, $\mathbb{S S} p \leq 0.01$, $\mathbb{S S S} p \leq 0.001$, between septic and healthy control mice, and " $p \leq 0.05$, *** $p \leq 0.01$, ${ }^{* * * *} p \leq 0.001$ between groups of septic mice.

\section{Results}

Overweight/obesity enhanced fatty acid mobilization during sepsis

In the first study (Table 1), we hypothesized that overweight/obese mice have an altered metabolic response to sepsis compared to the lean mice, with elevated mobilization and metabolism of endogenous fatty acids. In overweight/obese mice, initial fat pad weight was higher than in the lean mice $(910 \pm 128 \mathrm{mg}$ vs. $408 \pm 36$ mg; $p=0.01$ ). During their illness, overweight/obese septic mice lost about twice the amount of fat than did lean septic mice (day 5 fat pad weight $462 \pm 53 \mathrm{mg}$ in the overweight/obese vs. $162 \pm 42 \mathrm{mg}$ in the lean; $p=0.0006$ ) - After 1 day of sepsis, plasma glycerol and ex vivoreleased glycerol from adipose tissue (markers of lipolysis) were increased, which was more pronounced in overweight/obese than in lean mice (Fig. 1a,b). Nevertheless, during this acute phase of sepsis, both overweight/obese and lean septic mice presented with a similar plasma lipid profile as pair-fed controls, with low fatty acid, LDL- and HDL-cholesterol concentrations and normal triglyceride concentrations (Additional file 1: Figure S1). This suggested enhanced peripheral uptake of the released fatty acids during acute sepsis, especially in the overweight/obese mice. Indeed, sepsis-induced upregulation of fatty acid uptake transporter $C d 36$ mRNA in muscle and liver was most pronounced in the 


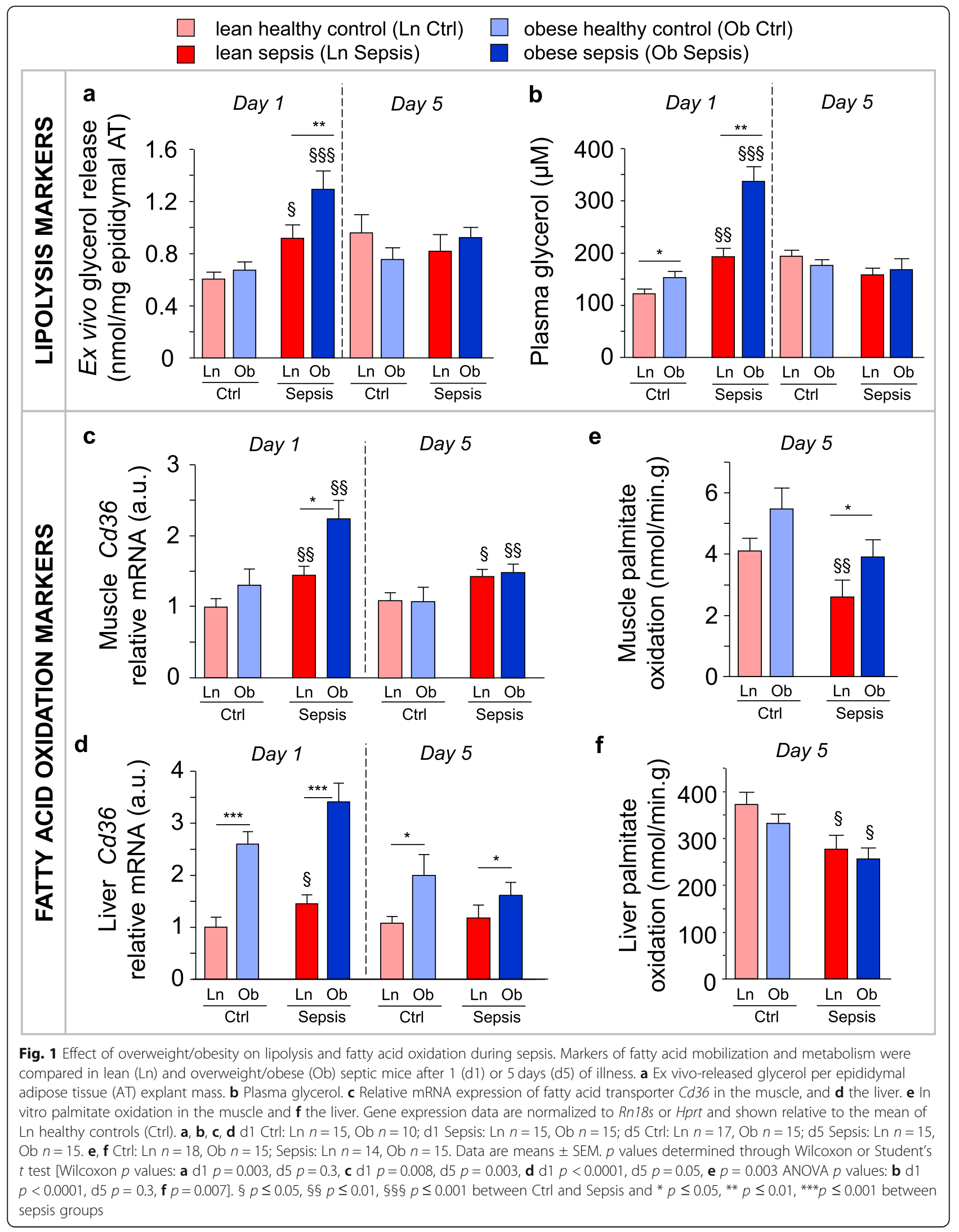


overweight/obese (Fig. 1c,d). Expression of other markers of hepatic and muscular fatty acid oxidation was generally unaffected by obesity or sepsis (Additional file 1: Figure S1).

After 5 days of sepsis, plasma and ex vivo-released glycerol from adipose tissue returned to control levels in both overweight/obese and lean septic mice (Fig. 1a,b). Plasma fatty acid, triglyceride and LDL-cholesterol concentrations normalized, whereas plasma HDL-cholesterol concentrations remained low (Additional file 1: Figure S1) . Nevertheless, hepatic and muscular Cd36 gene expression were still higher with sepsis, for liver only in overweight/obese mice (Fig. 1c, d). Furthermore, in these overweight/obese prolonged septic mice, in vitro palmitate oxidation in the muscle, but not the liver, remained up to control levels. In contrast, in vitro palmitate oxidation was reduced in the lean (Fig. 1e,f). Also during prolonged sepsis, gene expression of markers of hepatic and muscle fatty acid oxidation were generally unaffected by obesity or sepsis (Additional file 1: Figure S1).

\section{Blocking fatty acid mobilization in overweight/obese mice} caused sepsis-induced muscle wasting and weakness

In the second study (Table 1), we hypothesized that overweight/obese septic mice would no longer be protected against the loss of muscle mass and function when they are unable to release fatty acids from their excess adipose tissue. Blocking lipolysis via AAKO in overweight/obese mice indeed caused a greater loss of TA and EDL muscle mass after 5 days of sepsis compared to wild-type overweight/ obese mice (Fig. 2a,b). This more severe muscle wasting in the AAKO overweight/obese coincided with additional upregulation of the ubiquitin-proteasome system markers Fbxo32 and Trim63 (Fig. 2c). Furthermore, AAKO overweight/obese septic mice suffered from extremely reduced absolute ( $p<0.0001$ vs. AAKO healthy controls; Fig. 2d) and specific maximal muscle force (Fig. 2e). In contrast, wild-type overweight/obese septic mice displayed only slightly reduced absolute maximal force ( $p=0.01$ vs. wild-type healthy controls; Fig. $2 \mathrm{~d})$ and maintained specific maximal force up to healthy levels (Fig. 2e). AAKO overweight/obese septic mice also displayed a trend for a higher mortality rate than wild-type overweight/obese septic mice (Table 1) and had worse cumulative illness scores $(10.1 \pm 1.4$ in AAKO vs. $5.4 \pm 1.2$ in wild-type; $p=0.02$ ).

\section{Providing a lipid-rich parenteral infusion protected lean mice against sepsis-induced muscle weakness, but induced liver steatosis and a deranged lipid profile}

Results from the first two studies in overweight/obese mice identified the increased availability of endogenously released lipids as key in the protection against sepsisinduced muscle wasting and weakness. In the third study
(Table 1), we hypothesized that an increased lipid availability in lean septic mice would also protect them against sepsis-induced muscle wasting and weakness. However, after 5 days of sepsis, both lean mice that received standard mixed PN or lipid-rich PN presented with reduced TA and EDL muscle masses (Fig. 3a,b). Ubiquitin-proteasome system markers Fbxo32 and Trim63 mRNA were also comparably affected by sepsis in both groups of lean mice (Fig. 3c). As expected, lean septic mice on standard PN suffered from reduced absolute maximal muscle force ( $p<0.001$ vs. healthy controls; Fig. 3d) and specific maximal muscle force (Fig. 3e). In contrast, lean septic mice on lipid-rich PN showed less reduced absolute muscle force ( $p=0.05$ between standard PN and lipid-rich PN; Fig. 3d) and maintained their specific maximal muscle force equivalent to that of healthy controls (Fig. 3e).

Muscular and hepatic gene expression of fatty acid oxidation markers Cd36, Cpt1b, Acadl, and Hadha, and in vitro palmitate oxidation were highly increased in septic lean mice on lipid-rich PN compared to those on standard mixed PN (Fig. 4a-d). Importantly, giving high doses of lipids to lean septic mice did not adversely affect the mortality rate (Table 1), nor the cumulative illness scores $(7.1 \pm 1.1$ with lipid-rich PN vs. $6.2 \pm 0.9$ with standard mixed PN; $p=0.7)$. However, the lipid-rich PN did cause triglyceride accumulation in both the liver and the muscle (Fig. 4e,f). Furthermore, these mice also presented with histologically confirmed liver steatosis (global steatosis score: $2.72 \pm 1.54$ with lipid-rich PN vs. $1.56 \pm 1.03$ with standard mixed PN; $p=0.01$; Fig. $4 \mathrm{~g}$ ) and elevated plasma-free fatty acid, triglyceride, and LDL and HDL cholesterol concentrations (Fig. 4h-k).

\section{Enhanced lipid availability improved ketogenesis}

In a previous study, the protection against sepsisinduced muscle wasting and weakness in overweight/ obese mice coincided with elevated plasma concentration of ketone body 3-HB [15]. Here, we confirm the higher plasma 3-HB concentrations in overweight/obese septic mice than in the lean mice (Fig. 5a). Furthermore, these overweight/obese septic mice showed better preserved hepatic gene expression of the main ketogenic enzyme Hmgcs2 (Fig. 5b). Blocking lipolysis via AAKO in overweight/obese septic mice prevented the rise in plasma 3-HB concentrations and lowered the hepatic Hmgcs 2 mRNA expression, similar as in lean septic mice (Fig. 5a,b). In contrast, providing lean septic mice with lipid-rich PN drastically increased hepatic Hmgcs2 mRNA expression and plasma 3-HB concentrations (Fig. 5a,b). This elevated ketogenesis in the overweight/ obese and in lean mice receiving lipid-rich PN was not due to a change in plasma insulin concentrations (Additional file 2: Figure S2). Combined, these results suggest 


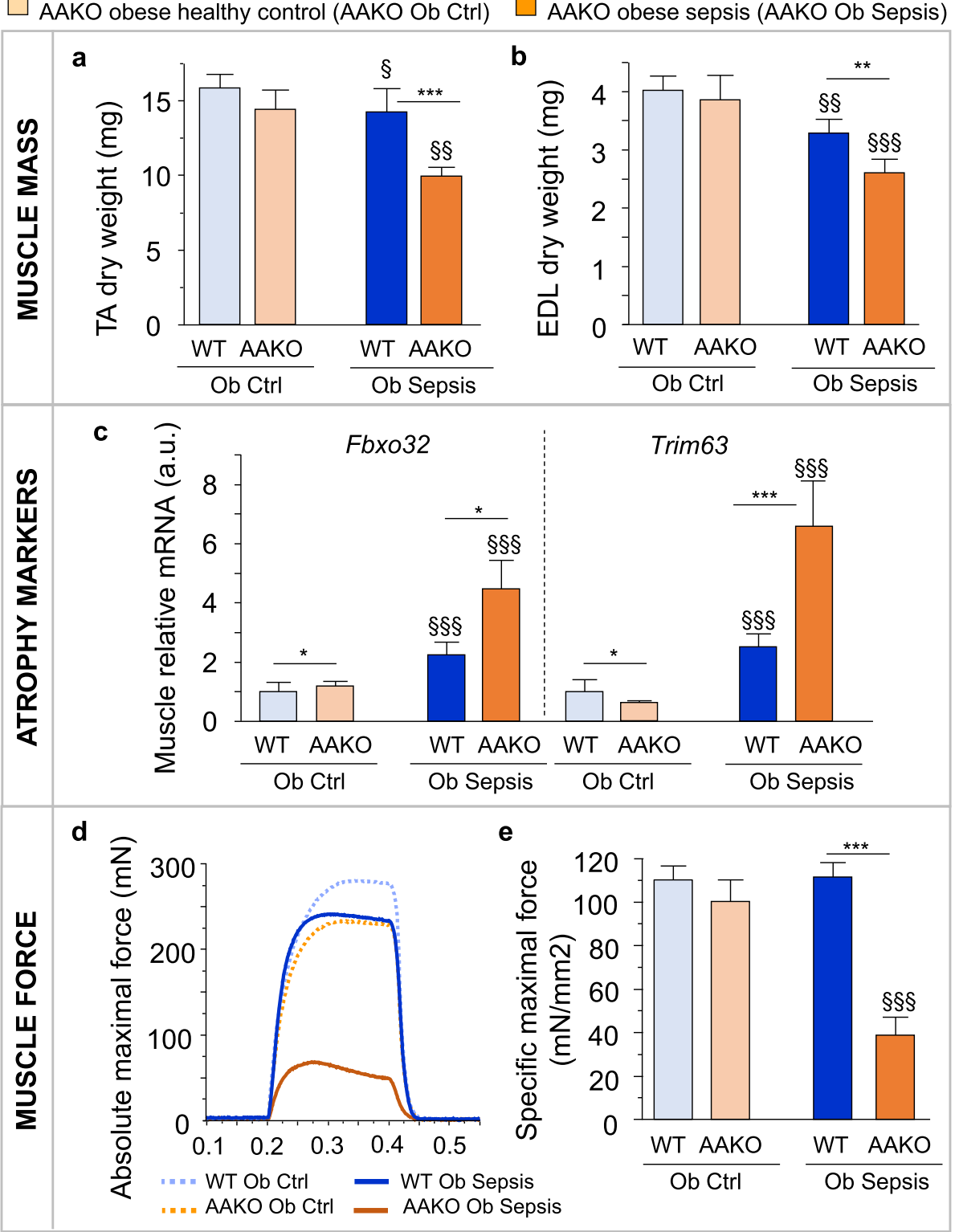

Fig. 2 Blocking lipolysis aggravated muscle wasting and weakness in overweight/obese septic mice. Markers of muscle wasting and weakness were assessed in overweight/obese (Ob) septic wild-type (WT) and adipose tissue-specific ATL knockout (AAKO) mice after 5 days of illness. a Tibialis anterior $(T A)$ and $\mathbf{b}$ extensor digitorum longus (EDL) muscle dry weight. $\mathbf{c}$ Relative mRNA expression of muscle atrophy markers. Gene expression data are normalized to Rn 18s and presented relative to the mean of WT Ob healthy controls (Ctrl). $\mathbf{d}$ Representative force tracings of ex vivo-measured absolute maximal tetanic force of the EDL muscle. e Ex vivo force measurements of the EDL indicating the specific maximal force (peak tetanic tension per unit muscle mass). a, b, c Ob Ctrl: WT $n=19$, AAKO $n=18$; Ob Sepsis: WT $n=19$, AAKO $n=17$. e Ob Ctrl: WT $n=17$, AAKO $n=14$; Ob Sepsis: WT $n=14$, AAKO $n=14$. Data are means \pm SEM. $p$ values determined through Wilcoxon Test [Wilcoxon $p$ values: a $p<0.0001, \mathbf{b} p<0.0001, \mathbf{c}$ Fbxo32 $p<0.0001$, Trim63 $p<$ 0.0001 , e $p<0.0001]$. $\S p \leq 0.05$, $\S p \leq 0.01, \S \S \S p \leq 0.001$ between Ctrl and Sepsis and ${ }^{*} p \leq 0.05,{ }^{* *} p \leq 0.01,{ }^{* * *} p \leq 0.001$ between sepsis groups

that ketone bodies may play an important role in the protection against muscle wasting and weakness.

\section{3-HB supplementation protected against sepsis-induced} muscle weakness and enhanced muscle regeneration In the fourth study (Table 1), we hypothesized that direct exogenous administration of ketone bodies can also protect lean septic mice against muscle wasting and weakness. After 5 days, all lean septic mice lost TA and EDL muscle mass, irrespective of 3-HB supplementation (Fig. 5c,d). However, 3-HB supplementation did prevent Fbxo32 mRNA upregulation (Fig. 5e). Similar to the lipid-rich PN, 3-HB supplementation in lean septic mice attenuated muscle weakness, with less reduced absolute 


\section{lean healthy control (Ln Ctrl) $\square$ lean sepsis receiving standard PN (Ln Sepsis PN) \\ lean sepsis receiving lipid-rich PN (Ln Sepsis Lipid)}

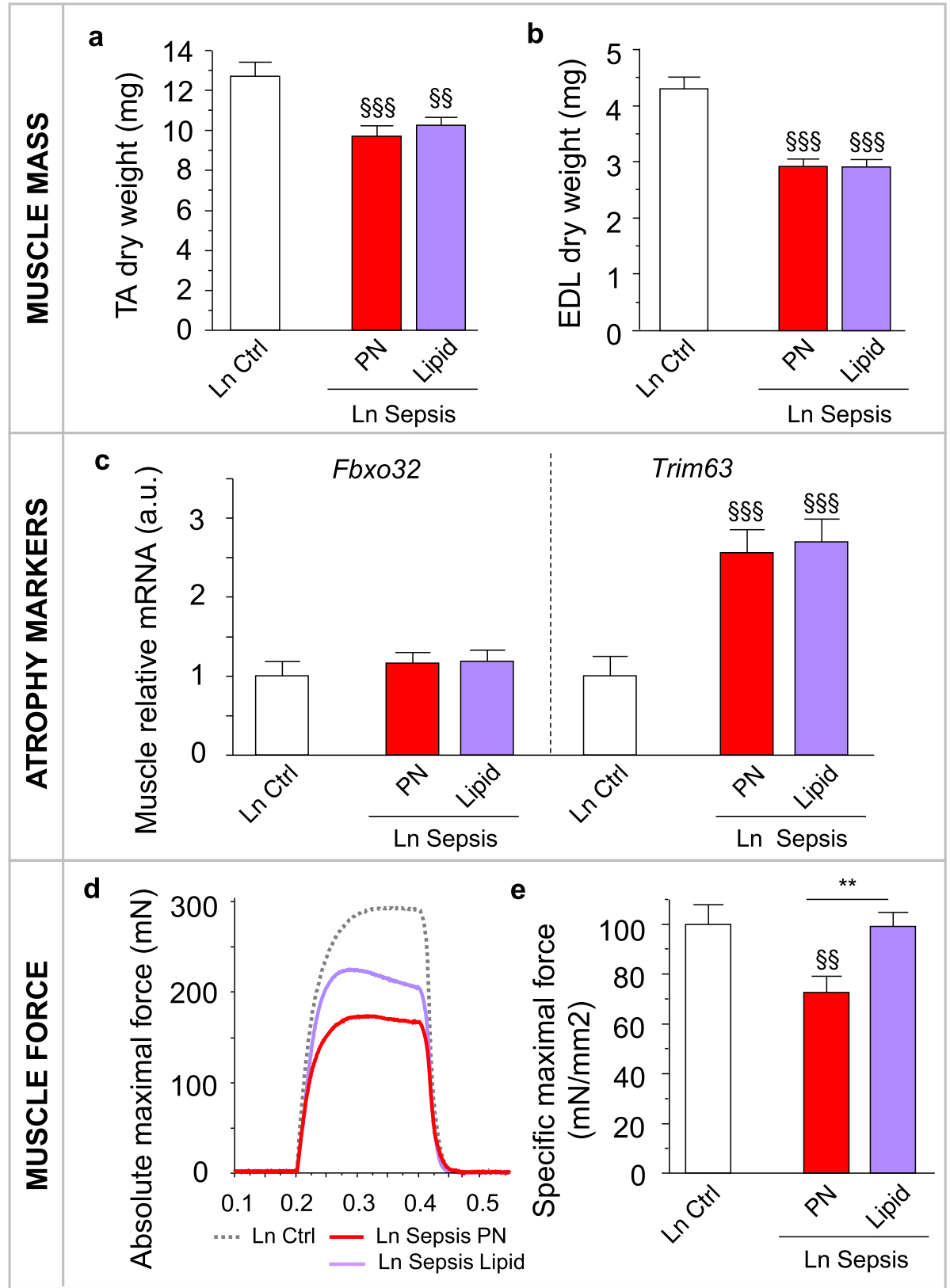

Fig. 3 Providing mixed long- and medium-chain triglycerides to lean septic mice protected against muscle weakness. Lean (Ln) septic mice were given either standard mixed parenteral nutrition (PN) or a lipid-rich PN (Lipid) containing a mix of long- and medium-chain triglycerides for 5 days. a Tibialis anterior (TA) and $\mathbf{b}$ extensor digitorum longus (EDL) muscle dry weight. $\mathbf{c}$ Relative mRNA expression of muscle atrophy markers. Gene expression data are normalized to Rn18s and shown relative to the mean of $\mathrm{Ln}$ healthy control mice (Ctrl). $\mathbf{d}$ Representative force tracings of ex vivo-measured absolute maximal tetanic force of the EDL muscle. e Ex vivo force measurements of the EDL indicating the specific maximal force (peak tetanic tension per unit muscle mass). a, b, $\mathbf{c} \operatorname{Ln} C \operatorname{trl} n=24$; Ln Sepsis: PN $n=23$, Lipid $n=23$. e $\operatorname{Ln}$ Ctrl $n=17$; Ln Sepsis: PN $n=16$, Lipid $n=15$. Data are means \pm SEM. $p$ values determined through Wilcoxon or Student's $t$ test [Wilcoxon $p$ values: c Fbxo32 $p=0.2$, Trim63 $p<$ 0.0001 ; ANOVA $p$ values: a $p=0.0008, \mathbf{b} p<0.0001$, e $p=0.01]$. $\S p \leq 0.05, \S \S p \leq 0.01$, $\S \S p \leq 0.001$ between Ctrl and Sepsis and ${ }^{*} p \leq 0.05$, ${ }^{* *} p \leq 0.01,{ }^{* * *} p \leq 0.001$ between Sepsis groups 


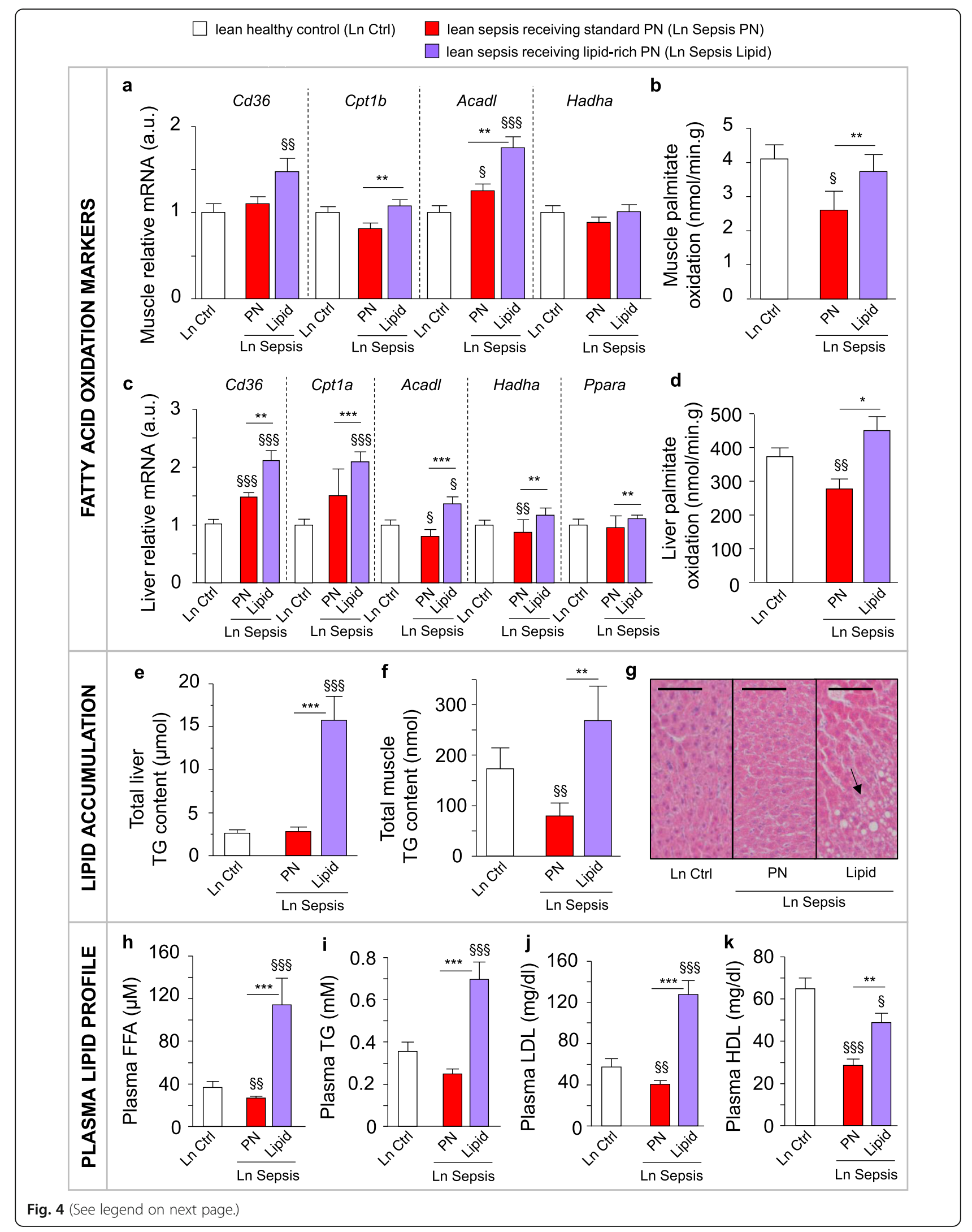




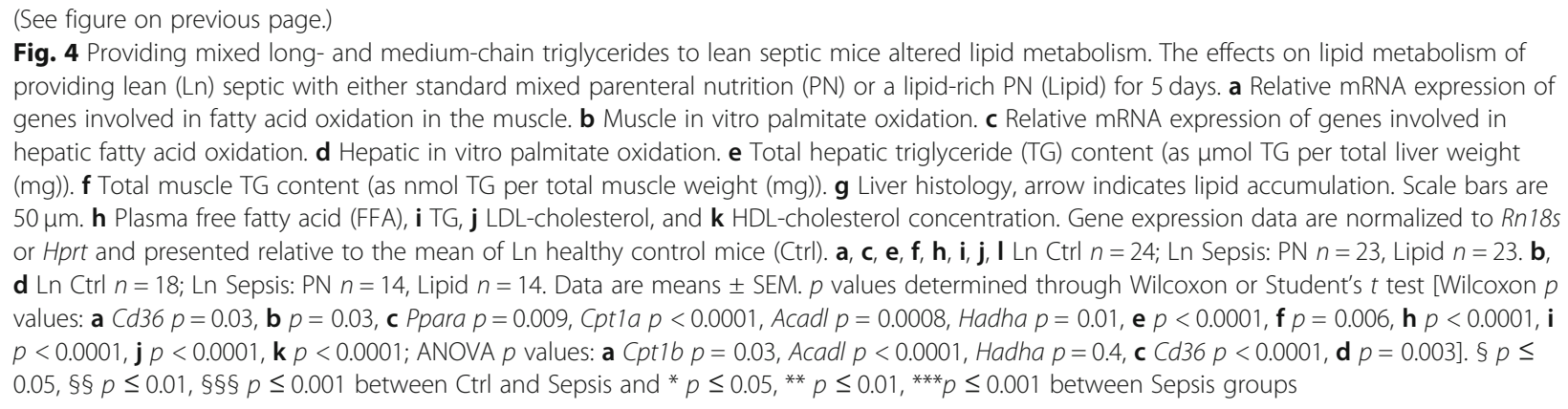

maximal muscle force $(p=0.002$ for $\mathrm{PN}+3-\mathrm{HB}$ vs. PN +gluc; Fig. 5f) and a specific maximal muscle force comparable to that of lean healthy control mice (Fig. $5 \mathrm{~g}$ ). PN $+3-\mathrm{HB}$ in lean septic mice did not affect mortality (Table 1) nor cumulative illness scores $(8.1 \pm 1.2$ with PN +3 -HB vs. $6.5 \pm 1.3$ with PN+gluc; $p=0.2$ ). Unlike lipidrich $\mathrm{PN}, \mathrm{PN}+3-\mathrm{HB}$ did not affect markers of fatty acid oxidation in muscle or liver (Additional file 3: Figure S3) or induce hepatic triglyceride accumulation (Additional file 3: Figure S3). Furthermore, 3-HB supplementation partially normalized the plasma lipid profile (Additional file 3: Figure S3). In the muscle of $\mathrm{PN}+3-\mathrm{HB}$ septic mice, markers of ketolysis, the triglyceride and glycogen content, and plasma glucose concentrations were decreased or unaltered compared to $\mathrm{PN}+$ gluc (Additional file 3: Figure S3). Together, these results argue against the use of $3-\mathrm{HB}$ as an alternative energy substrate by the muscle during critical illness.

Several signaling functions have been attributed to 3$\mathrm{HB}$ as well: $3-\mathrm{HB}$ has known anti-inflammatory and autophagy-activating properties and can stimulate mTOR-mediated protein synthesis. However, the illnessinduced effects on these pathways were not altered by 3HB supplementation (Additional file 4: Figure S4). In contrast, $\mathrm{PN}+3-\mathrm{HB}$ did have effects on pathways involved in muscle regeneration. Whereas the number of PAX7-positive muscle satellite cells was unaffected by illness (Fig. 6a), gene expression of proliferation marker Pcna was clearly increased by sepsis, especially with PN +3-HB (Fig. 6b). As compared to PN+gluc, PN+3-HB increased the expression of regeneration markers Myod1, $M y o g$, and $M y f 5$ in lean septic mice (Fig. 6b). Furthermore, $\mathrm{PN}+3-\mathrm{HB}$ caused a greater reduction in gene expression of myostatin, an inhibitor of muscle growth (Fig. 6b). Both groups of septic mice showed similarly increased expression of the muscle acetylcholine receptor (AchR) $\alpha$-polypeptide gene (Chrna1) (Fig. 6c). This gene encodes for the $\alpha$-subunit that is present in all AchRs. Expression of the adult AchR $\varepsilon$-subunit gene (Chrne) that is found in mature myofibers was most reduced in lean $\mathrm{PN}+3-\mathrm{HB}$ septic mice (Fig. 6c). In contrast, PN+3$\mathrm{HB}$ caused a four times higher increase than $\mathrm{PN}+$ gluc in the expression of the embryonic AchR $\gamma$-subunit gene (Chrng), found in immature myofibers (Fig. 6c). These 3$\mathrm{HB}$ supplemented lean septic mice also presented with a greater elevation of Actb mRNA than the PN+gluc septic mice (Fig. 6d). Of note, histone deacetylases (HDAC) 4 and 5 are known inhibitors of the muscle regeneration pathway by blocking the expression of myogenic transcription factor MEF2. In lean septic mice receiving PN $+3-\mathrm{HB}$, muscular expression of Hdac4 and Hdac5 was suppressed (Fig. 6e). Furthermore, Mef2c mRNA was higher in lean $\mathrm{PN}+3-\mathrm{HB}$ than lean $\mathrm{PN}+$ gluc ill mice (Fig. 6e).

\section{Discussion}

We here showed that overweight/obese septic mice had more pronounced lipolysis, peripheral fatty acid oxidation, and ketogenesis than did lean mice. Blocking lipolysis abolished the overweight/obesity-induced protection of the muscle, whereas high intravenous doses of lipids attenuated muscle weakness in lean septic mice. Although this nutritional strategy enhanced fatty acid oxidation and ketogenesis, it also caused adverse liver steatosis and a deranged lipid profile. Ketone body supplementation to $\mathrm{PN}$ in lean septic mice also attenuated muscle weakness and improved muscle regeneration without such adverse effects.

Critical illness in lean patients is characterized by impaired ketogenesis and reduced hepatic and muscular fatty acid metabolism [41-43]. Remarkably, overweight/ obese septic mice did not display such impairment but maintained the typical metabolic profile present with diet-induced obesity (enhanced lipolysis and elevated hepatic fatty acid metabolism) [16-20, 22, 23]. Furthermore, this obesity-induced enhanced lipolysis appears crucial during sepsis. Indeed, blocking lipolysis in overweight/obese septic mice profoundly aggravated muscle wasting and weakness. Also in healthy non-obese mice, insufficient availability of adipose tissue-derived fatty acids via AAKO caused reduced exercise performance [44]. This demonstrates an important role of lipid availability for normal muscle function. 

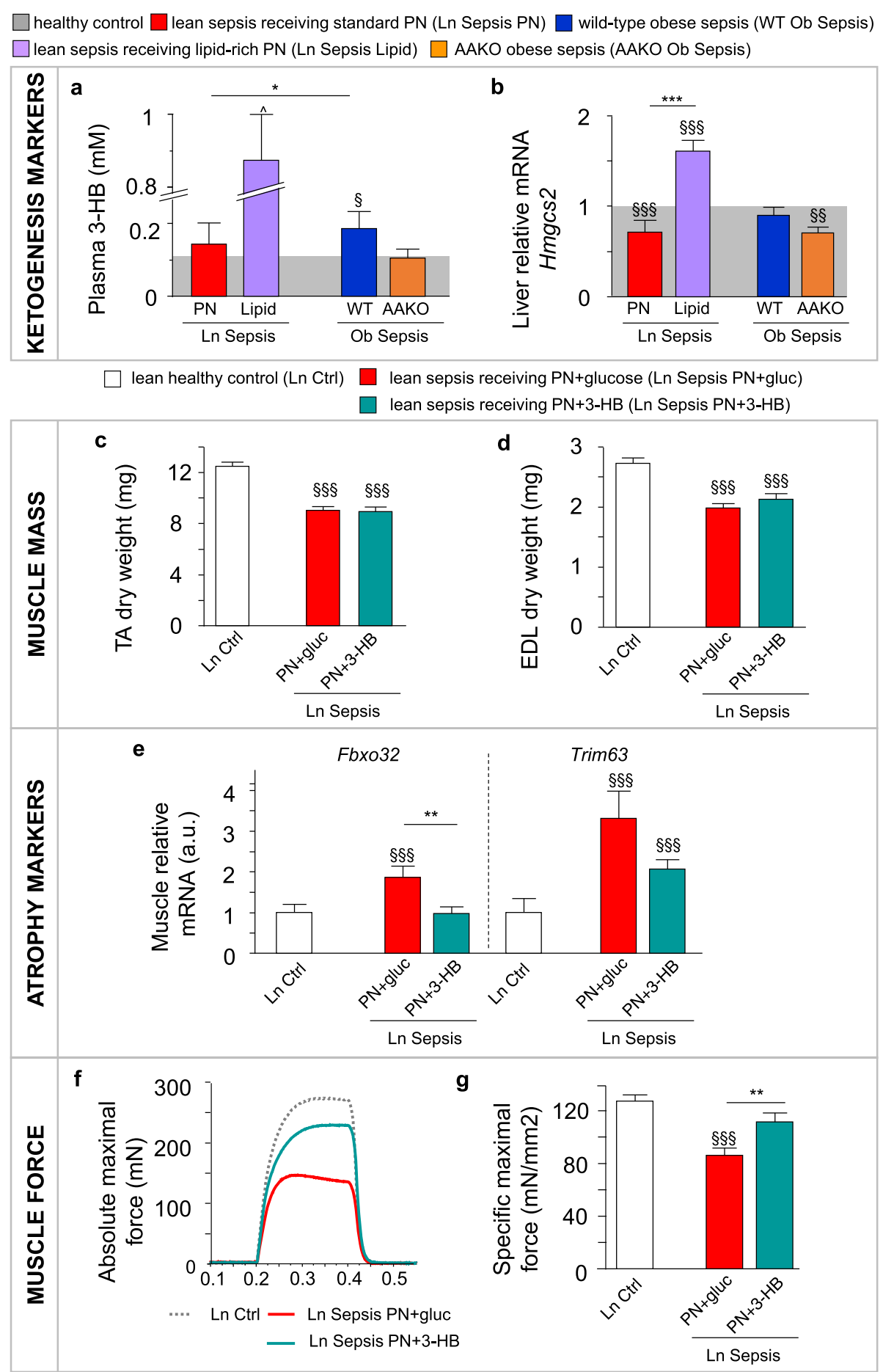

Fig. 5 (See legend on next page.)

With these four consecutive animal studies, we have identified the mechanisms underlying the protection against sepsis-induced muscle wasting and weakness in overweight/obese mice. Whether a similar mechanism holds true for human patients requires further investigation. We previously demonstrated that after 1 week of critical illness, overweight/obese patients showed better preservation of myofiber size and suffered less from ICU-acquired weakness [15]. A small pilot feasibility study did confirm larger initial muscle depth in obese critically ill patients but failed to demonstrate a difference over time [45]. In general, the potential benefit of 


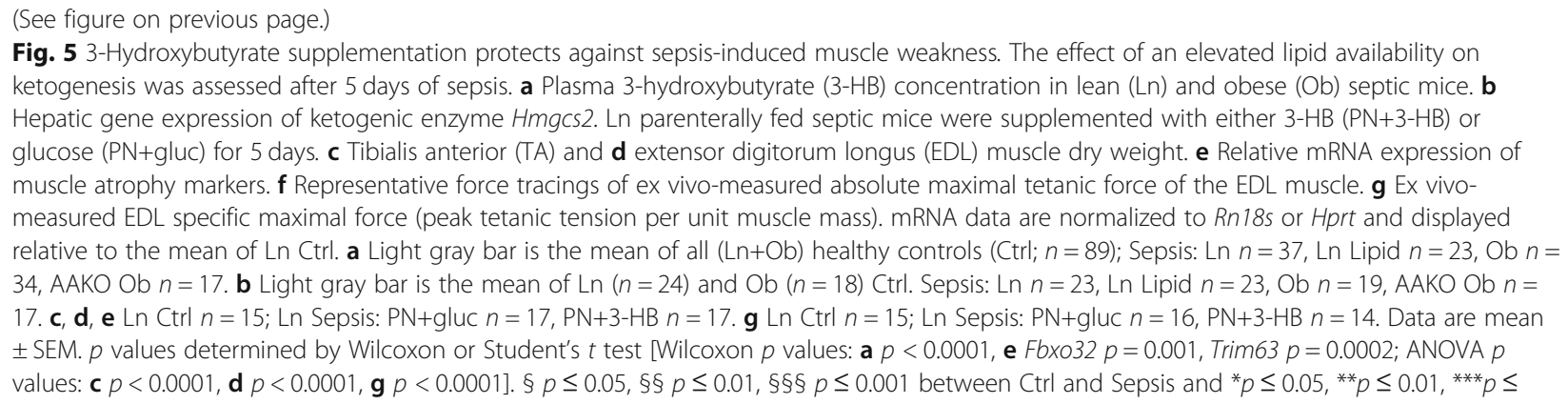

overweight/obesity in critically ill patients has mainly been investigated in relation to mortality. Better ICU survival has been observed in overweight/obese patients compared to those who are underweight, have a normal weight, or are morbidly obese [46-49]. As ICU-acquired weakness is an independent risk factor for death in the ICU $[2,50]$, the overweight/obesity-induced protection of the muscle may, to a certain extent, contribute to the observed survival benefit.

Both premorbid overweight/obesity and treatment with high lipid doses enhanced ketogenesis and resulted in elevated plasma 3-HB concentrations. Furthermore, 3-HB supplementation to $\mathrm{PN}$ in lean ill septic mice could mimic the protective effect of giving high lipid doses and of overweight/obesity on muscle weakness. This suggests that ketogenesis is key in protecting against sepsis-induced muscle weakness. In line with our findings, exogenous supplementation of ketone bodies has been shown to improve physical endurance performance in both rats and elite athletes [25, 51]. In contrast, other supplementation studies did not show enhanced physical performances in trained men [52-54].

Neither the supplementation of $\mathrm{PN}$ with $3-\mathrm{HB}$ nor the infusion of high lipid doses in lean septic mice could replicate the observed overweight/obesity-induced protection against muscle wasting [15]. This suggests that the preservation of muscle mass in the overweight/obese is likely related to other pathways. Possibly, the adipokine leptin could be implicated. Indeed, leptin has been shown to increase muscle mass and to reduce muscle atrophy [55-57]. Leptin concentrations also strongly correlate with adiposity, resulting in higher concentrations in obesity [58]. Of note, in other neuromuscular disorders such as cancer cachexia, increasing plasma ketone body concentrations did have an effect on muscle mass [24, 59]. Furthermore, 3-HB infusion decreased wholebody phenylalanine-to-tyrosine degradation in LPSinduced inflammation in humans, but had no beneficial effect on protein metabolism in septic patients [60, 61]. Hence, the exact effect of $3-\mathrm{HB}$ on muscle mass in critically ill patients should also be further investigated.
Nevertheless, the observation that $\mathrm{PN}+3-\mathrm{HB}$ during sepsis directly reduced muscle weakness has clear clinical potential. Whereas a beneficial effect on muscle force was also observed with high lipid doses, the observed side effects limit the therapeutic potential of this type of nutrition. Furthermore, the skeletal muscle appears to be bio-energetically inert for delivered lipids during chronic critical illness [43]. This observation further argues for a direct effect of ketones on muscle weakness, rather than of increased lipid availability.

The muscle protection of $\mathrm{PN}+3-\mathrm{HB}$ during sepsis does not appear to be related to its use as an energy substrate, but rather by its effects as a signaling molecule [28, 29, $62]$. In contrast to cerebral or active muscle 3-HB uptake and oxidation, 3-HB uptake in the resting skeletal muscle of healthy individuals displays saturation kinetics [63]. This may explain why supplemented ketones appeared to function as signaling molecules rather than energy substrates in our sick mice. Indeed, 3-HB clearly increased markers of early muscle regeneration and decreased the expression of class IIa HDACs. These deacetylases are known suppressors of the regeneration pathway through suppression of MEF2 [64-67]. Further research is needed to evaluate a direct link between improved muscle regeneration and muscle function by 3$\mathrm{HB}$. It is also unclear whether 3-HB supplementation of $\mathrm{PN}$ in lean septic mice does not only prevent but also restore muscle function when weakness is present. Given that muscle regeneration is impaired in the human critically ill and hampers longer-term recovery [12], the observed effect of 3-HB on muscle regeneration may hold great promise also for optimizing longer-term recovery of patients.

An important limitation of our study is the use of a mouse model to study ICU-acquired weakness. Hence, translation to the human patient should be done with caution, given several species-specific differences [68]. Nevertheless, the model of sepsis-induced muscle wasting and weakness resembles human ICU-acquired weakness. The septic mice were also fluid-resuscitated and received antibiotics, analgesia, and nutritional support. 


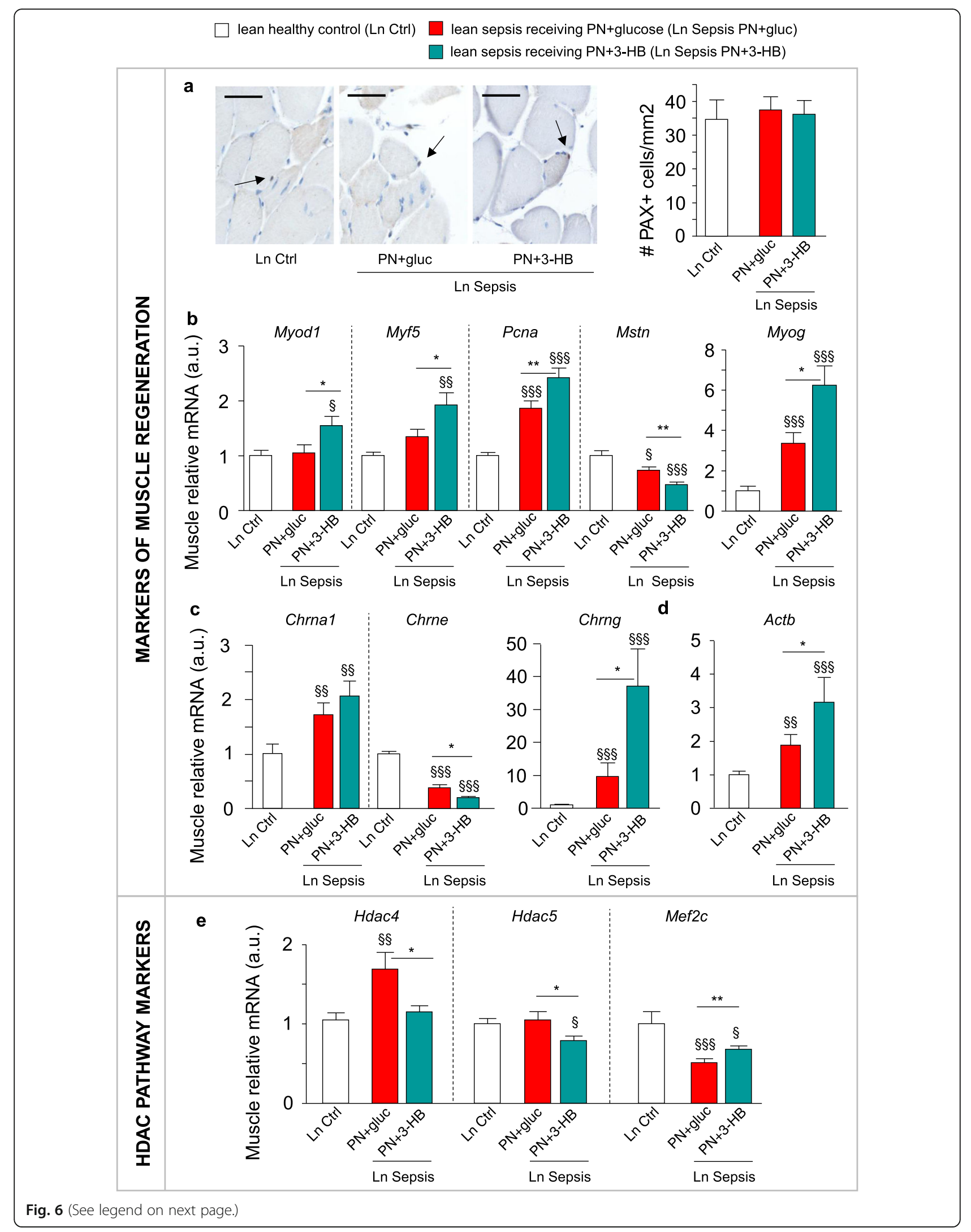


(See figure on previous page.)

Fig. 6 3-HB supplementation enhanced markers of muscle regeneration. Markers related to muscle regeneration were evaluated in lean ( $L n)$ parenterally fed septic mice, supplemented with either 3-hydroxybutyrate (PN+3-HB) or glucose (PN+gluc) for 5 days. a Muscle PAX+ satellite cell staining and quantification of number of PAX+ cells per area. Arrow indicates PAX+ cells. Scale bar is $25 \mu \mathrm{m}$. b Relative muscular mRNA expression of genes involved in muscle regeneration, $\mathbf{c}$ genes encoding acetylcholine receptor subunits, $\mathbf{d}$ the beta-actin encoding gene, and $\mathbf{e}$ HDAC class II encoding genes and downstream targets. Gene expression data are normalized to Rn 18 s and presented relative to the mean of $L n$ healthy controls (Ctrl). All panels: Ln Ctrl $n=15$; Ln Sepsis: PN+gluc $n=17, \mathrm{PN}+3-\mathrm{HB} n=17$. Data are means \pm SEM. $p$ values determined through Wilcoxon or Student's $t$ test [Wilcoxon $p$ values: a $p=0.6$, b Myod1 $p=0.03$, Myf5 $p=0.01$, Msth $p=0.0002$, Myog $p<0.0001, \mathbf{c}$ Chrna1 $p=0.01$, Chrng $p<0.0001$, Chrne $p<0.0001$, d $p=0.0002$, e Hdac4 $p=0.01$, Mef2c $p=0.0004$; ANOVA $p$ values: b Pcna $p<0.0001$, e Hdac5 $p=0.05]$. $\$ p \leq$ $0.05, \S \S p \leq 0.01, \S \S \S p \leq 0.001$ between Ctrl and Sepsis and ${ }^{*} p \leq 0.05,{ }^{* *} p \leq 0.01,{ }^{* * *} p \leq 0.001$ between Sepsis groups

However, they were not mechanically ventilated nor did they receive other routinely used pharmacological agents that may contribute to the development of ICU-acquired weakness in patients [4]. Second, for certain pathways, we could rely on gene expression data alone, which might not always be reflected in protein changes as well. Third, we did not assess whether specific macronutrients of the standard PN played either a synergistic or antagonistic role in the observed protection with 3-HB supplementation. Indeed, it was demonstrated earlier that early provision of PN worsened weakness and slowed down recovery $[9,69,70]$, which was largely attributable to the administered proteins [71, 72].

\section{Conclusions}

The obesity-induced muscle protection during sepsis was partly mediated by elevated mobilization and metabolism of endogenous fatty acids. Increased lipid availability in lean septic mice not only protected against muscle weakness, but also induced adverse side effects. Both overweight/obesity and a lipid-rich $\mathrm{PN}$ in lean mice stimulated ketogenesis. As direct supplementation of 3$\mathrm{HB}$ to $\mathrm{PN}$ in lean septic mice also protected against muscle weakness, these ketones appear to play a key role in the observed muscle protection. Furthermore, $\mathrm{PN}+3-$ HB specifically activated muscle regeneration pathways, which may contribute to attenuated muscle weakness also in the longer term. Going from observations in overweight/obese septic mice to interventions in the lean mice, it is now clear that supplementation of 3-HB should be further investigated as a novel metabolic strategy to prevent debilitating muscle weakness in critically ill human patients.

\section{Additional files}

Additional file 1: Figure S1. Plasma lipid profile and markers of fatty acid oxidation in lean and overweight/obese mice. The plasma lipid profile and gene expression markers of fatty acid oxidation were assessed in lean (Ln) and overweight/obese (Ob) mice after 1 (d1) or 5 days (d5) of sepsis. (a) Plasma free fatty acid (FFA), (b) triglyceride (TG), (c) LDLcholesterol, and (d) HDL-cholesterol concentrations. (e) Relative mRNA expression of genes involved in fatty acid oxidation in the muscle. (f) Relative mRNA expression of genes involved in hepatic fatty acid oxidation. Gene expression data are normalized to Rn18s or Hprt and shown relative to the mean of $\operatorname{Ln}$ healthy controls (Ctrl). For all panels: d1 Ctrl: $\operatorname{Ln} n=15$, Ob $n=10$; d1 Sepsis: $\operatorname{Ln} n=15, \mathrm{Ob} n=15$; d5 Ctrl: $\operatorname{Ln} n=17$, Ob $n=15$; d5 Sepsis: $\operatorname{Ln} n=15$, Ob $n=15$. Data are mean \pm SEM. $p$ values determined through Wilcoxon or Student's $t$ tests [Wilcoxon $p$ values: (a) d1 $p$ $=0.01, \mathrm{~d} 5 p=0.6$, (b) d1 $p=0.5, \mathrm{~d} 5 p=0.5$, (e) d1 Acadl $p=0.07, \mathrm{~d} 1$ Hadha $p=0.2$, d5 Hadha $p=0.05$, (f) d1 Ppara $p=0.7$, d5 Ppara $p<$ 0.0001 , d1 Cpt1a $p=0.1, \mathrm{~d} 5$ Cpt1a $p=0.1$ d5 Acadl $p=0.003$, d5 Hadha $p$ $=0.001$; ANOVA $p$ values: (c) d1 $p<0.0001, \mathrm{~d} 5 p=0.4$, (d) $\mathrm{d} 1 p<0.0001$, d5 $p=0.002$, (e) d1 Cpt1b $p=0.1$, d5 Cpt1b $p=0.1$, d5 Acadl $p=0.002$, (f) d1 Acadl $p=0.003$, d1 Hadha $p=0.2] . \S p \leq 0.05, \S \S p \leq 0.01, \S \S \S p \leq$ 0.001 between Ctrl and Sepsis, ${ }^{*} p \leq 0.05,{ }^{* *} p \leq 0.01,{ }^{* * *} p \leq 0.001$ between sepsis groups. (DOCX $220 \mathrm{~kb}$ )

Additional file 2: Figure S2. Plasma insulin. Plasma insulin concentrations after 5 days of sepsis in (a) lean (Ln) and overweight/ obese (Ob) mice and (b) in Ln mice receiving either standard mixed parenteral nutrition (PN), or a lipid-rich PN (Lipid). (a) Healthy control (Ctrl): $\operatorname{Ln} n=17$, Ob $n=15$; d5 Sepsis: $\operatorname{Ln} n=15$, Ob $n=15$. (b): Ln Ctrl $n$ $=24$; Ln Sepsis: PN $n=23$, Lipid $n=23$. Data are means \pm SEM. $p$ values determined through Wilcoxon or Student's $t$ test [Wilcoxon $p$ values: (a) $p=0.1$, (b) $p=0.01]$. $\S p \leq 0.05$, $\S \S p \leq 0.01$, $\S \S \S \leq 0.001$ between Ctrl and Sepsis, ${ }^{*} p \leq 0.05,{ }^{* *} p \leq 0.01,{ }^{* * *} p \leq 0.001$ between sepsis groups. (DOCX $40 \mathrm{~kb}$ )

Additional file 3: Figure S3. Ketone body 3-HB does not appear to function as alternative energy substrate during sepsis. The effect of supplementation of glucose (PN+gluc) or 3-hydroxybutyrate (PN+3-HB) to lean (Ln) parenterally fed mice was evaluated after 5 days of sepsis. (a) Relative mRNA of genes involved in muscle and (b) hepatic fatty acid oxidation. (c) Total triglyceride (TG) content of the muscle (as nmol TG per total muscle weight (mg)) and (d) the liver (as $\mu \mathrm{mol}$ TG per total liver weight (mg)). (e) Plasma free fatty acid (FFA), (f) TG, (g) LDL-cholesterol, and (h) HDL-cholesterol concentration. (i) Relative mRNA of genes involved in ketolysis. (j) Plasma glucose concentrations. (k) Total glycogen content of the muscle (as $\mu \mathrm{g}$ glycogen per total muscle weight $(\mathrm{mg})$ ). Gene expression data are normalized to Rn18s or Hprt and presented relative to mean of $\mathrm{Ln}$ healthy controls (Ctrl). All panels: $\mathrm{Ln} \mathrm{Ctrl} n=15$; $\mathrm{Ln}$ Sepsis: PN+gluc $n=17, P N+3-H B n=17$. Data are means \pm SEM. $p$ values determined through Wilcoxon or Student's $t$ test [Wilcoxon $p$ values: (a) $C d 36 p=0.1$, Cpt1b $p=0.6$, Acadl $p=0.03$, Hadha $p=0.3$, (b) Ppara $p=$ 0.002 , Cd36 $p=0.05$, (c) $p=0.001$, (d) $p=0.6$, (e) $p=0.2$, (f) $p=0.004$, (g) $p=0.01$, (h) $p<0.0001$, (i) Mct1 $p=0.0008$, Mct2 $p=0.8$, Oxct1 $p=0.01$, (j) $p<0.0001$ (k) $p=0.2$; ANOVA $p$ values: (b) Cpt1a $p=0.4$, Acadl $p<0.0001$, Hadha $p<0.0001]$. $\S p \leq 0.05, \S \S p \leq 0.01$, $\S \S p \leq 0.001$ between Ctrl and Sepsis, ${ }^{*} p \leq 0.05,{ }^{* *} p \leq 0.01,{ }^{* * *} p \leq 0.001$ between sepsis groups (DOCX $286 \mathrm{~kb}$ )

Additional file 4: Figure S4. Effect of 3-HB on markers of autophagy, inflammation and mTOR-related protein synthesis. The effect of supplementation of glucose ( $\mathrm{PN}+$ gluc) or 3-hydroxybutyrate (PN+3-HB) to lean (Ln) parenterally fed mice was evaluated after 5 days of sepsis. (a) Relative expression of genes and (b) proteins involved in autophagy in the muscle. (c) Relative mRNA expression of genes involved in the inflammatory response in the muscle. (d) Plasma TNF-a concentration. (e) Relative expression of proteins involved in mTOR-related protein synthesis. Gene expression data are normalized to Rn18s or Hprt and presented relative to the mean of $\mathrm{Ln}$ healthy controls (Ctrl). Protein expression data are normalized to b-actin and displayed relative to the mean of $\mathrm{Ln} C \mathrm{Crrl}$. All panels: $\operatorname{Ln} \mathrm{Ctrl} n=15$; Ln Sepsis: PN+gluc $n=17, \mathrm{PN}+3-\mathrm{HB} n=17$. Data 
are means \pm SEM. $p$ values determined through Wilcoxon Test Wilcoxon $p$ values: (a) Atg5 $p=0.01$, Atg $7 p<0.0001$, Sqstm $1 p<0.0001$, (b) pULK1/ ULK1 $p=0.7$, p62 $p=0.0004$, LC3 II/I $p=0.01$, (c) Tnfa $p=0.005$, II1b $p=$ 0.0006, N/rp3 $p<0.0001$, (d) $p<0.0001$, (e) pS6K1/S6K1 $p=0.002$, 4EBP1Y/4E-BP1 $p=0.6]$. $\S p \leq 0.05, \S \S p \leq 0.01$, $\S \S p \leq 0.001$ between Ctrl and Sepsis, ${ }^{*} p \leq 0.05,{ }^{* *} p \leq 0.01,{ }^{* *} p \leq 0.001$ between sepsis groups (DOCX $101 \mathrm{~kb}$ )

Additional file 5: Figure S5. Confirmation of adipose tissue-specific ATGL knockout. Markers of adipose tissue-specific ATGL knockout (AAKO) were assessed in overweight/obese (Ob) wild-type (WT) and knockout mice. (a) Relative mRNA expression of Pnpla2/Atgl in visceral (visc.) and subcutaneous (s.c.) adipose tissue (AT), muscle and liver. (b) Summation of visc., s.c., and epididymal AT depot weights after 5 days, as percentage of initial body weight. (c) Plasma glycerol concentration. (d) Ex vivo glycerol release per epididymal AT explant mass. (e) Plasma free fatty acid (FFA) concentration. (f) Relative mRNA expression of genes involved in hepatic fatty acid oxidation. Gene expression data are normalized to Rn18s or Hprt and presented relative to the mean of WT Ob healthy controls (Ctrl). For all panels: Ob Ctrl: WT $n=19$, AAKO $n=18$; Ob Sepsis: WT $n=19$, AAKO $n=17$. Data are mean \pm SEM. $p$ values determined through Wilcoxon or Student's $t$ test [Wilcoxon $p$ values: (a) visc. AT $p<0.0001$, s.c. AT $p<0.0001$, muscle $p<0.0001$, liver $p=0.002$, (d) $p<0.0001$, (f) Ppara $p=0.0002$, Cd36 $p<0.0001$, Cpt1a $p=0.01$; ANOVA $p$ values: (b) $p<$ 0.0001 , (c) $p<0.0001$, (e) $p=0.003$, (f) Acadl $p=0.9$, Hadha $p=0.07$ ]. § $p \leq 0.05, \S \S p \leq 0.01, \S \S \S p \leq 0.001$ between Ctrl and Sepsis, ${ }^{*} p \leq 0.05$, ${ }^{* *} p \leq 0.01,{ }^{* *} p \leq 0.001$ between sepsis groups. (DOCX $219 \mathrm{~kb}$ )

Additional file 6: Table S1. List of commercial TagMan ${ }^{\oplus}$ assays used for gene analyses. (DOCX $17 \mathrm{~kb}$ )

Additional file 7: Supplemental Material and Methods. (DOCX 83 kb)

\section{Abbreviations}

3-HB: 3-Hydroxybutyrate; AAKO: Adipose tissue-specific ATGL knockout: AchR: Acetylcholine receptor; ATGL: Adipose triglyceride lipase; EDL: Extensor digitorum longus; HDAC: Histone deacetylase; ICU: Intensive care unit; PN: Parenteral nutrition; TA: Tibialis anterior

\section{Acknowledgements}

We thank Inge Derese for her excellent technical assistance.

\section{Authors' contributions}

$C G, L L, G V d B$, and $S D$ conceived and designed the experiments. CG, SD, and TD performed the mice studies. CG, RW, SVP, TD, LP, and SD performed the experiments and analyzed the data. PPW and SET contributed expertise and help with experiments. CG, $L \mathrm{~L}$, and $\mathrm{GVdB}$ wrote the paper. All authors reviewed and approved the manuscript.

\section{Funding}

$\mathrm{GVdB}$ and $\mathrm{LL}$, via the $\mathrm{KU}$ Leuven, receive long-term structural research support from the Methusalem Program funded by the Flemish Government (METH14/06) and from the Research Foundation Flanders (G.0C78.17N). This project has received funding from the European Research Council (ERC) under the European Union's Horizon 2020 research and innovation program [AdvG 2017-785809].

\section{Availability of data and materials}

The datasets used and/or analyzed during the current study are available from the corresponding author on reasonable request.

\section{Ethics approval and consent to participate}

The Institutional Ethical Committee for Animal Experimentation of the KU Leuven had approved the protocols for these animal studies (project numbers P50/2015 and P009/2016).

\section{Consent for publication}

Not applicable.

\section{Competing interests}

$\mathrm{CG}, \mathrm{GVdB}$, and $\mathrm{LL}$ are inventors on a pending patent application related to the content of the manuscript (PCT/EP2017/081394).

\section{Author details}

Clinical Division and Laboratory of Intensive Care Medicine, Department of Cellular and Molecular Medicine, KU Leuven, 3000 Leuven, Belgium.

${ }^{2}$ Laboratory for Lipid Biochemistry and Protein Interactions, Department of

Cellular and Molecular Medicine, KU Leuven, 3000 Leuven, Belgium.

Received: 16 November 2018 Accepted: 4 June 2019

Published online: 01 July 2019

\section{References}

1. Fletcher SN, Kennedy DD, Ghosh IR, Misra VP, Kiff K, Coakley JH, Hinds CJ. Persistent neuromuscular and neurophysiologic abnormalities in long-term survivors of prolonged critical illness. Crit Care Med. 2003;31(4):1012-6.

2. Hermans $G$, Van Mechelen H, Clerckx B, Vanhullebusch T, Mesotten D, Wilmer A, Casaer MP, Meersseman P, Debaveye Y, Van Cromphaut S, et al. Acute outcomes and 1-year mortality of intensive care unit-acquired weakness. A cohort study and propensity-matched analysis. Am J Respir Crit Care Med. 2014;190(4):410-20.

3. Schefold JC, Bierbrauer J, Weber-Carstens S. Intensive care unit-acquired weakness (ICUAW) and muscle wasting in critically ill patients with severe sepsis and septic shock. J Cachexia Sarcopenia Muscle. 2010;1(2):147-57.

4. Hermans $G$, Van den Berghe $G$. Clinical review: intensive care unit acquired weakness. Crit Care. 2015;19:274.

5. Derde S, Hermans G, Derese I, Guiza F, Hedstrom Y, Wouters PJ, Bruyninckx F, D'Hoore A, Larsson L, Van den Berghe G, et al. Muscle atrophy and preferential loss of myosin in prolonged critically ill patients. Crit Care Med. 2012;40(1):79-89.

6. Puthucheary ZA, Rawal J, McPhail M, Connolly B, Ratnayake G, Chan P, Hopkinson NS, Phadke R, Dew T, Sidhu PS, et al. Acute skeletal muscle wasting in critical illness. Jama. 2013;310(15):1591-600.

7. Jespersen JG, Nedergaard A, Reitelseder S, Mikkelsen UR, Dideriksen K, Agergaard J, Kreiner F, Pott FC, Schjerling P, Kjaer M. Activated protein synthesis and suppressed protein breakdown signaling in skeletal muscle of critically ill patients. PLoS One. 2011;6(3):e18090.

8. Klaude M, Mori M, Tjader I, Gustafsson T, Wernerman J, Rooyackers O. Protein metabolism and gene expression in skeletal muscle of critically ill patients with sepsis. Clin Sci. 2012;122(3):133-42.

9. Hermans G, Casaer MP, Clerckx B, Guiza F, Vanhullebusch T, Derde S, Meersseman P, Derese I, Mesotten D, Wouters PJ, et al. Effect of tolerating macronutrient deficit on the development of intensive-care unit acquired weakness: a subanalysis of the EPaNIC trial. Lancet Respir Med. 2013;1(8): $621-9$.

10. Derde S, Vanhorebeek I, Guiza F, Derese I, Gunst J, Fahrenkrog B, Martinet W, Vervenne $H$, Ververs EJ, Larsson L, et al. Early parenteral nutrition evokes a phenotype of autophagy deficiency in liver and skeletal muscle of critically ill rabbits. Endocrinology. 2012;153(5):2267-76.

11. Friedrich $O$, Reid MB, Van den Berghe $G$, Vanhorebeek I, Hermans G, Rich MM, Larsson L. The sick and the weak: neuropathies/myopathies in the critically ill. Physiol Rev. 2015;95(3):1025-109.

12. Dos Santos C, Hussain SN, Mathur S, Picard M, Herridge M, Correa J, Bain A, Guo Y, Advani A, Advani SL, et al. Mechanisms of chronic muscle wasting and dysfunction after an intensive care unit stay. A pilot study. Am J Respir Crit Care Med. 2016;194(7):821-30.

13. Hermans G, Wilmer A, Meersseman W, Milants I, Wouters PJ, Bobbaers H, Bruyninckx F, Van den Berghe G. Impact of intensive insulin therapy on neuromuscular complications and ventilator dependency in the medical intensive care unit. Am J Respir Crit Care Med. 2007;175(5):480-9.

14. Van den Berghe G, Schoonheydt K, Becx P, Bruyninckx F, Wouters PJ. Insulin therapy protects the central and peripheral nervous system of intensive care patients. Neurology. 2005;64(8):1348-53.

15. Goossens C, Marques MB, Derde S, Vander Perre S, Dufour T, Thiessen SE, Guiza F, Janssens T, Hermans G, Vanhorebeek I, et al. Premorbid obesity, but not nutrition, prevents critical illness-induced muscle wasting and weakness. J Cachexia Sarcopenia Muscle. 2017;8(1):89-101.

16. Large V, Reynisdottir S, Langin D, Fredby K, Klannemark M, Holm C, Arner P. Decreased expression and function of adipocyte hormone-sensitive lipase in subcutaneous fat cells of obese subjects. J Lipid Res. 1999:40(11):2059-66.

17. Reynisdottir S, Langin D, Carlstrom K, Holm C, Rossner S, Arner P. Effects of weight reduction on the regulation of lipolysis in adipocytes of women with upper-body obesity. Clin Sci. 1995;89(4):421-9. 
18. Stevens J, Green MH, Kaiser DL, Pohl SL. Insulin resistance in adipocytes from fed and fasted obese rats: dissociation of two insulin actions. Mol Cell Biochem. 1981;37(3):177-83.

19. Hickner RC, Racette SB, Binder EF, Fisher JS, Kohrt WM. Suppression of whole body and regional lipolysis by insulin: effects of obesity and exercise. J Clin Endocrinol Metab. 1999:84(11):3886-95.

20. Nicklas BJ, Rogus EM, Colman EG, Goldberg AP. Visceral adiposity, increased adipocyte lipolysis, and metabolic dysfunction in obese postmenopausal women. Am J Phys. 1996;270(1 Pt 1):E72-8.

21. Abella V, Scotece M, Conde J, Pino J, Gonzalez-Gay MA, Gomez-Reino JJ, Mera A, Lago F, Gomez R, Gualillo O. Leptin in the interplay of inflammation, metabolism and immune system disorders. Nat Rev Rheumatol. 2017;13(2):100-9.

22. Satapati S, Sunny NE, Kucejova B, Fu X, He TT, Mendez-Lucas A, Shelton JM, Perales JC, Browning JD, Burgess SC. Elevated TCA cycle function in the pathology of diet-induced hepatic insulin resistance and fatty liver. J Lipid Res. 2012;53(6):1080-92.

23. lozzo P, Bucci M, Roivainen A, Nagren K, Jarvisalo MJ, Kiss J, Guiducci L, Fielding B, Naum AG, Borra R, et al. Fatty acid metabolism in the liver, measured by positron emission tomography, is increased in obese individuals. Gastroenterology. 2010;139(3):846-56 856 e841-846.

24. Shukla SK, Gebregiworgis T, Purohit V, Chaika NV, Gunda V, Radhakrishnan P, Mehla K, Pipinos II, Powers R, Yu F, et al. Metabolic reprogramming induced by ketone bodies diminishes pancreatic cancer cachexia. Cancer Metab. 2014:2:18.

25. Cox PJ, Kirk T, Ashmore T, Willerton K, Evans R, Smith A, Murray AJ, Stubbs B, West J, McLure SW, et al. Nutritional ketosis alters fuel preference and thereby endurance performance in athletes. Cell Metab. 2016;24(2):256-68

26. Veech RL, Chance B, Kashiwaya Y, Lardy HA, Cahill GF Jr. Ketone bodies, potential therapeutic uses. IUBMB Life. 2001;51(4):241-7.

27. Gano LB, Patel M, Rho JM. Ketogenic diets, mitochondria, and neurological diseases. J Lipid Res. 2014:55(11):2211-28.

28. Camberos-Luna L, Geronimo-Olvera C, Montiel T, Rincon-Heredia R, Massieu $\mathrm{L}$. The ketone body, beta-Hydroxybutyrate stimulates the Autophagic flux and prevents neuronal death induced by glucose deprivation in cortical cultured neurons. Neurochem Res. 2016:41(3):600-9.

29. Youm YH, Nguyen KY, Grant RW, Goldberg EL, Bodogai M, Kim D, D'Agostino D, Planavsky N, Lupfer C, Kanneganti TD, et al. The ketone metabolite beta-hydroxybutyrate blocks NLRP3 inflammasome-mediated inflammatory disease. Nat Med. 2015;21(3):263-9.

30. Nair KS, Welle SL, Halliday D, Campbell RG. Effect of beta-hydroxybutyrate on whole-body leucine kinetics and fractional mixed skeletal muscle protein synthesis in humans. J Clin Invest. 1988;82(1):198-205.

31. Vandoorne T, De Smet S, Ramaekers M, Van Thienen R, De Bock K, Clarke K, Hespel P. Intake of a ketone Ester drink during recovery from exercise promotes mTORC1 signaling but not glycogen Resynthesis in human muscle. Front Physiol. 2017;8:310.

32. Zou X, Meng J, Li L, Han W, Li C, Zhong R, Miao X, Cai J, Zhang Y, Zhu D. Acetoacetate accelerates muscle regeneration and ameliorates muscular dystrophy in mice. J Biol Chem. 2016;291(5):2181-95.

33. Derde $\mathrm{S}$, Thiessen S, Goossens C, Dufour T, Van den Berghe G, Langouche L. Use of a central venous line for fluids, drugs and nutrient administration in a mouse model of critical illness. JoVE. 2017;123:art.nr. 55553.

34. Marques MB, Vander Perre S, Aertgeerts A, Derde S, Guiza F, Casaer MP, Hermans G, Van den Berghe G, Langouche L. Critical illness induces nutrient-independent adipogenesis and accumulation of alternatively activated tissue macrophages. Crit Care. 2013;17(5):R193.

35. Langford DJ, Bailey AL, Chanda ML, Clarke SE, Drummond TE, Echols S, Glick $\mathrm{S}$, Ingrao J, Klassen-Ross T, Lacroix-Fralish ML, et al. Coding of facial expressions of pain in the laboratory mouse. Nat Methods. 2010;7(6):447-9.

36. Langouche L, Vander Perre S, Thiessen S, Gunst J, Hermans G, D'Hoore A, Kola B, Korbonits M, Van den Berghe $\mathrm{G}$. Alterations in adipose tissue during critical illness: an adaptive and protective response? Am J Respir Crit Care Med. 2010;182(4):507-16

37. Nias I, Vassiliadi DA, Theodorakopoulou M, Boutati E, Maratou E, Mitrou P, Nikitas N, Apollonatou S, Dimitriadis G, Armaganidis A, et al. Adipose tissue lipolysis and circulating lipids in acute and subacute critical illness: effects of shock and treatment. J Crit Care. 2014;29(6):1130 e1135-1139.

38. Langouche L, Marques MB, Ingels C, Gunst J, Derde S, Vander Perre S, D'Hoore A, Van den Berghe G. Critical illness induces alternative activation of M2 macrophages in adipose tissue. Crit Care. 2011;15(5):R245.
39. Langouche L, Vanhorebeek I, Vlasselaers D, Vander Perre S, Wouters PJ, Skogstrand K, Hansen TK, Van den Berghe G. Intensive insulin therapy protects the endothelium of critically ill patients. J Clin Invest. 2005;115(8):2277-86.

40. Van Veldhoven P, Mannaerts GP. Comparison of the activities of some peroxisomal and extraperoxisomal lipid-metabolizing enzymes in liver and extrahepatic tissues of the rat. Biochem J. 1985;227(3):737-41.

41. Beisel WR, Wannemacher RW Jr. Gluconeogenesis, ureagenesis, and ketogenesis during sepsis. JPEN J Parenter Enteral Nutr. 1980;4(3):277-85.

42. Birkhahn RH, Long CL, Fitkin DL, Busnardo AC, Geiger JW, Blakemore WS. A comparison of the effects of skeletal trauma and surgery on the ketosis of starvation in man. J Trauma. 1981;21(7):513-9.

43. Puthucheary ZA, Astin R, McPhail MJW, Saeed S, Pasha Y, Bear DE, Constantin D, Velloso C, Manning S, Calvert L, et al. Metabolic phenotype of skeletal muscle in early critical illness. Thorax. 2018;73(10):926-35.

44. Dube JJ, Sitnick MT, Schoiswohl G, Wills RC, Basantani MK, Cai L, Pulinilkunnil T, Kershaw EE. Adipose triglyceride lipase deletion from adipocytes, but not skeletal myocytes, impairs acute exercise performance in mice. Am J Phys Endocrinol Metab. 2015;308(10):E879-90.

45. Segaran $E$, Wandrag $L$, Stotz $M$, Terblanche $M$, Hickson M. Does body mass index impact on muscle wasting and recovery following critical illness? A pilot feasibility observational study. J Hum Nutr Diet. 2017;30(2):227-35.

46. Akinnusi ME, Pineda LA, El Solh AA. Effect of obesity on intensive care morbidity and mortality: a meta-analysis. Crit Care Med. 2008;36(1):151-8.

47. Hogue CW Jr, Stearns JD, Colantuoni E, Robinson KA, Stierer T, Mitter N, Pronovost PJ, Needham DM. The impact of obesity on outcomes after critical illness: a meta-analysis. Intensive Care Med. 2009;35(7):1152-70.

48. Peake SL, Moran JL, Ghelani DR, Lloyd AJ, Walker MJ. The effect of obesity on 12-month survival following admission to intensive care: a prospective study. Crit Care Med. 2006:34(12):2929-39.

49. Pickkers P, de Keizer N, Dusseljee J, Weerheijm D, van der Hoeven JG, Peek N. Body mass index is associated with hospital mortality in critically ill patients: an observational cohort study. Crit Care Med. 2013;41(8):1878-83.

50. Ali NA, O'Brien JM Jr, Hoffmann SP, Phillips G, Garland A, Finley JC, Almoosa K, Hejal R, Wolf KM, Lemeshow S, et al. Acquired weakness, handgrip strength, and mortality in critically ill patients. Am J Respir Crit Care Med. 2008;178(3):261-8.

51. Murray AJ, Knight NS, Cole MA, Cochlin LE, Carter E, Tchabanenko K, Pichulik T, Gulston MK, Atherton HJ, Schroeder MA, et al. Novel ketone diet enhances physical and cognitive performance. FASEB J. 2016;30(12): 4021-32.

52. O'Malley T, Myette-Cote E, Durrer C, Little JP. Nutritional ketone salts increase fat oxidation but impair high-intensity exercise performance in healthy adult males. Appl Physiol Nutr Metab. 2017;42(10):1031-5.

53. Scott BE, Laursen PB, James LJ, Boxer B, Chandler Z, Lam E, Gascoyne T, Messenger J, Mears ST. The effect of 1,3-butanediol and carbohydrate supplementation on running performance, J Sci Med Sport. 2019;22(6):702706.

54. Shaw DM, Merien F, Braakhuis A, Plews D, Laursen P, Dulson DK. The effect of 1,3-Butanediol on cycling time-trial performance. Int J Sport Nutr Exerc Metab. 2019:1-27.

55. Sainz N, Rodriguez A, Catalan V, Becerril S, Ramirez B, Gomez-Ambrosi J, Fruhbeck $\mathrm{G}$. Leptin administration favors muscle mass accretion by decreasing FoxO3a and increasing PGC-1alpha in Ob/Ob mice. PLoS One. 2009;4(9):e6808.

56. Bartell SM, Rayalam S, Ambati S, Gaddam DR, Hartzell DL, Hamrick M, She JX, Della-Fera MA, Baile CA. Central (ICV) leptin injection increases bone formation, bone mineral density, muscle mass, serum IGF-1, and the expression of osteogenic genes in leptin-deficient Ob/Ob mice. J Bone Miner Res. 2011;26(8):1710-20.

57. Hamrick MW, Herberg S, Arounleut P, He HZ, Shiver A, Qi RQ, Zhou L, Isales CM, Mi QS. The adipokine leptin increases skeletal muscle mass and significantly alters skeletal muscle miRNA expression profile in aged mice. Biochem Biophys Res Commun. 2010;400(3):379-83.

58. Considine RV, Sinha MK, Heiman ML, Kriauciunas A, Stephens TW, Nyce MR, Ohannesian JP, Marco CC, McKee LJ, Bauer TL, et al. Serum immunoreactiveleptin concentrations in normal-weight and obese humans. N Engl J Med. 1996:334(5):292-5

59. Nakamura K, Tonouchi H, Sasayama A, Ashida K. A ketogenic formula prevents tumor progression and Cancer Cachexia by attenuating systemic inflammation in Colon 26 tumor-bearing mice. Nutrients. 2018;10(2).

60. Beylot M, Chassard D, Chambrier C, Guiraud M, Odeon M, Beaufrere B, Bouletreau P. Metabolic effects of a D-beta-hydroxybutyrate infusion in 
septic patients: inhibition of lipolysis and glucose production but not leucine oxidation. Crit Care Med. 1994;22(7):1091-8.

61. Thomsen HH, Rittig N, Johannsen M, Moller AB, Jorgensen JO, Jessen N, Moller N. Effects of 3-hydroxybutyrate and free fatty acids on muscle protein kinetics and signaling during LPS-induced inflammation in humans: anticatabolic impact of ketone bodies. Am J Clin Nutr. 2018;108(4):857-67.

62. Ahola-Erkkila S, Carroll CJ, Peltola-Mjosund K, Tulkki V, Mattila I, SeppanenLaakso T, Oresic M, Tyynismaa H, Suomalainen A. Ketogenic diet slows down mitochondrial myopathy progression in mice. Hum Mol Genet. 2010; 19(10):1974-84.

63. Mikkelsen KH, Seifert T, Secher NH, Grondal T, van Hall G. Systemic, cerebral and skeletal muscle ketone body and energy metabolism during acute hyper-D-beta-hydroxybutyratemia in post-absorptive healthy males. J Clin Endocrinol Metab. 2015;100(2):636-43.

64. Berkes CA, Tapscott SJ. MyoD and the transcriptional control of myogenesis. Semin Cell Dev Biol. 2005;16(4-5):585-95.

65. Miska EA, Langley E, Wolf D, Karlsson C, Pines J, Kouzarides T. Differential localization of HDAC4 orchestrates muscle differentiation. Nucleic Acids Res. 2001;29(16):3439-47.

66. Moresi V, Marroncelli N, Coletti D, Adamo S. Regulation of skeletal muscle development and homeostasis by gene imprinting, histone acetylation and microRNA. Biochim Biophys Acta. 2015;1849(3):309-16.

67. Giordani L, Puri PL. Epigenetic control of skeletal muscle regeneration: integrating genetic determinants and environmental changes. FEBS J. 2013; 280(17):4014-25

68. Radermacher P, Haouzi P. A mouse is not a rat is not a man: species-specific metabolic responses to sepsis - a nail in the coffin of murine models for critical care research? Intensive Care Med Exp. 2013;1(1):26.

69. Casaer MP, Mesotten D, Hermans G, Wouters PJ, Schetz M, Meyfroidt G, Van Cromphaut S, Ingels C, Meersseman P, Muller J, et al. Early versus late parenteral nutrition in critically ill adults. N Engl J Med. 2011;365(6):506-17.

70. Fivez T, Kerklaan D, Mesotten D, Verbruggen S, Wouters PJ, Vanhorebeek I, Debaveye Y, Vlasselaers D, Desmet L, Casaer MP, et al. Early versus late parenteral nutrition in critically ill children. N Engl J Med. 2016;374(12):1111-22.

71. Casaer MP, Wilmer A, Hermans G, Wouters PJ, Mesotten D, Van den Berghe G. Role of disease and macronutrient dose in the randomized controlled EPaNIC trial: a post hoc analysis. Am J Respir Crit Care Med. 2013;187(3):247-55.

72. Vanhorebeek I, Verbruggen S, Casaer MP, Gunst J, Wouters PJ, Hanot J, Guerra GG, Vlasselaers D, Joosten K, Van den Berghe G. Effect of early supplemental parenteral nutrition in the paediatric ICU: a preplanned observational study of post-randomisation treatments in the PEPaNIC trial. Lancet Respir Med. 2017;5(6):475-83.

\section{Publisher's Note}

Springer Nature remains neutral with regard to jurisdictional claims in published maps and institutional affiliations.

Ready to submit your research? Choose BMC and benefit from:

- fast, convenient online submission

- thorough peer review by experienced researchers in your field

- rapid publication on acceptance

- support for research data, including large and complex data types

- gold Open Access which fosters wider collaboration and increased citations

- maximum visibility for your research: over $100 \mathrm{M}$ website views per year

At $\mathrm{BMC}$, research is always in progress.

Learn more biomedcentral.com/submissions 